Ю. Рева,

аспірант кафедри адміністративного та фінансового права Національного університету «Одеська юридична академія»

\title{
ОСОБЛИВОСТІ ПРИТЯГНЕННЯ ДО АДМІНІСТРАТИВНОЇ ВІДПОВІДАЛЬНОСТІ ЗА ПОРУШЕННЯ ВИМОГ ФІНАНСОВОГО КОНТРОЛЮ
}

Актуальність

дослідження. Незважаючи на вироблення нормативного та інституційного механізмів протидії та запобігання корупції, вона продовжує існувати в українському суспільстві, набуваючи інших форм. Неточність формулювань щодо сутності корупційних правопорушень, включаючи адміністративні делікти призводить до звільнення від відповідальності. Теоретично вірне обгрунтування визначення підстав притягнення до адміністративної відповідальності за вчинення корупційного правопорушення у формі порушення вимог фінансового контролю забезпечить ефективність системи електронного декларування для осіб, яких уповноважено на виконання функцій держави або місцевого самоврядування.

Дослідженням проблеми корупції займалися такі вчені, як: В.Б. Авер'янов, А.О. Васьковцов, С.Л. Дембіцька, В.К. Колпаков, М.I. Мельник, В.M. Санжаровець, О.П. Хамходера та ряд інших. Проте станом на теперішній час не має єдиного теоретико-правового підходу до визначення підстав притягнення до відповідальності за вчинення правопорушення, якого передбачено ст. $172^{6}$ Кодексу України про адміністративні правопорушення. Саме тому, метою статті $€$ окреслення особливостей підстави притягнення до відповідальності осіб, яких уповноважено на виконання функцій держави або місцевого самоврядування за порушення вимог фінансового контролю.

Виклад основного матеріалу. Корупцію у залежності від ступеня сус- пільної небезпеки та заподіяної шкоди може бути кваліфіковано як злочин або як проступок. При чому, особу може бути притягнуто до кримінальної, адміністративної, дисциплінарної чи цивільно-правової відповідальності. Одним із наслідків порушення системи електронного декларування особами, яких уповноважено на виконання функцій держави або місцевого самоврядування є притягнення до адміністративної відповідальності.

Відповідно до Закону України «Про запобігання корупціі», несвоєчасного поданням без поважних причин декларації, неповідомлення або несвоєчасного повідомлення про суттєві зміни у майновому стані, а також подання завідомо недостовірних відомостей у декларації $€$ правопорушенням, якого пов'язано 3 корупцією, а не корупційним правопорушенням. Вказана група правопорушень не містить ознак корупції, але порушує встановлені законом вимоги, заборони та обмеження, вчинені визначеною законом особою, за які законом встановлено кримінальну, адміністративну, дисциплінарну та/ або цивільно-правову відповідальність [1]. При цьому, проступку у вигляді порушення вимог фінансового контролю притаманні як загальні, так і особливі ознаки. До загальних ознак належать наступні:

1) правопорушення виступає суспільно небезпечним діянням;

2) правопорушення являється протиправною дією чи бездіяльністю;

3) правопорушення являється винною (умисну або необережну) дією чи бездіяльністю; 


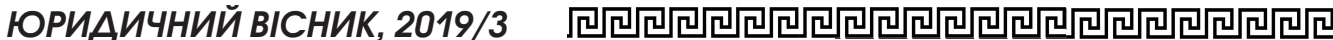

4) правопорушення посягає на об’єкти, які знаходяться під охороною адміністративного законодавства;

5) правопорушення являється фактичною підставою для притягнення до адміністративної відповідальності;

6) за вчинення правопорушення передбачено застосування санкцій, яких передбачено адміністративним законодавством тощо [2].

Щодо окреслення специфіки адміністративного проступку у вигляді порушення вимог фінансового контролю, ii опосередковано тим, що це: протиправне винне діяння виражено у порушенні встановлених законом вимог, заборон та обмежень щодо здійснення публічної служби [3, с. 2]; є протиправним винним діянням, яке може бути вчинено особами уповноваженими на виконання функцій держави або місцевого самоврядування, прирівняними до них, та особами, які постійно або тимчасово обіймають посади, пов'язані з виконанням організаційно-розпорядчих чи адміністративно-господарських обов'язків, або спеціально уповноваженими на виконання таких обов'язків у юридичних особах приватного права незалежно від організаційно-правової форми; воно посягає на сферу суспільних відносин, яких пов'язано з здійсненням публічного адміністрування та забезпеченням прав і свобод громадян [4, с. 62]; матеріально-правовою основою притягнення до відповідальності є сукупність нормативно-правових актів у сфері запобігання корупції тощо.

Як вид адміністративного правопорушення, недотриманню вимог фінансового контролю притаманний конкретний склад. Під складом правопорушення розуміється сукупність закріплених у правових нормах об'єктивних та суб'єктивних ознак, якими створено цілісне відображення про визначений вид правопорушення, і які $€$ єдиною фактичною підставою для притягнення до юридичної відповідальності.

Склад порушення вимог фінансового контролю утворюють:
1) об'єктивні ознаки: об'єкт правопорушення та об'єктивна сторона правопорушення;

2) суб'єктивні ознаки: суб'єкт правопорушення та суб'єктивна сторона правопорушення [5, с. 261].

Об'єктом порушення вимог фінансового контролю є суспільні відносини, яких пов'язано з здійснення публічної служби. У законодавстві України сутність поняття «порядок здійснення публічної служби» не визначено. Під «порядком» розуміють певним чином врегульований стан суспільних відносин; стан, коли все робиться, виконується так, як слід, відповідно до певних вимог, правил [6, с. 888]. Цей термін може бути використаним у значенні процедури, механізму реалізації повноважень, прав і обов'язків, вчинення відповідних дій суб'єктами правовідносин $[7$, с. 660$]$.

Здійснення публічної служби спрямовано на задоволення публічного інтересу, не може здійснюватися винятково на підставі приватного розсуду, оскільки це неминуче призведе до порушень прав, свобод і законних інтересів приватних осіб, а також розбалансування діяльності самої публічної адміністрації. Публічне право регулює побудову (як створені) та функціонування (як діють) насамперед органів державної влади та органів місцевого самоврядування, а також інших суб'єктів (наприклад суб'єктів делегованих повноважень), що мають забезпечувати реалізацію публічних інтересів [8, с. 57].

Поняття «публічна служба» міститься в Кодексі адміністративного судочинства України та визначено як діяльність на державних політичних посадах, професійна діяльність суддів, прокурорів, військова служба, альтернативна (невійськова) служба, дипломатична служба, інша державна служба, служба в органах влади АРK, органах місцевого самоврядування [9]. Вказане визначення публічної служби потребує уточнення, так як не містить сутнісних характеристик та особливос- 
тей публічної діяльності, у ньому наводиться лише перелік видів цієї діяльності, що є порушенням правил юридичної техніки. За таких обставин з'ясування поняття, сутності, особливостей і видів публічної служби і публічних службовців набуває особливого значення.

Як слушно зазначає Л.Р. Біла-Тіунова, сутність публічної служби полягає в трьох аспектах, а саме: у функціональному аспекті вона постає як діяльність з метою виконання загальнодержавних завдань управління; в інституційному - окреслює певне коло осіб, оскільки виконання публічних справ становить їх соціальну функцію; в юридичному - охоплює правове регулювання особливих публічно-правових, службових відносин, які, у свою чергу, поділяються на чиновницькі і відносини найманих осіб-службовців та робітників державних установ [10, с. 144].

Таким чином, родовим об’єктом порушення вимог фінансового контролю $€$ суспільні відносини, яких пов'язано із механізмом реалізації повноважень, прав і обов'язків, вчинення відповідних дій суб'єктами, яких уповноважено на здійснення виконання завдань і функцій держави, спрямованих на забезпечення публічних інтересів. Видовим об'єктом $€$ суспільні відносини, яких пов'язано із механізмом дотримання вимог щодо здійснення публічної служби.

Об'єктивна сторона правопорушення - це зовнішня сторона протиправної діяльності. Описуючи те чи інше правопорушення, законодавець частіше вказує на ознаки саме об'єктивної сторони. До них належать: суспільно небезпечне діяння (дія чи бездіяльність), наслідки й причинний зв'язок між ними.

Ознакою об'єктивної сторони порушення вимог фінансового контролю являється діяння, яке вчинено у формі пасивної дії: несвоєчасного поданням без поважних причин декларації неповідомлення або несвоєчасного повідомлення про відкриття валютного рахунка в установі банку-нерезидента; неповідомлення або несвоєчасного повідомлення про суттєві зміни у майновому стані, а також у формі активної діï - подання завідомо недостовірних відомостей у декларації особи [2].

Відповідно до Перехідних положень Закону України «Про запобігання корупції, про початок роботи системи подання та оприлюднення відповідно декларацій осіб, уповноважених на виконання функцій держави або місцевого самоврядування, приймається рішення Національного агентства з питань запобігання корупції [1]. Станом на теперішній час Єдиний державний реєстр декларацій осіб, уповноважених на виконання функцій держави або місцевого самоврядування функціонує та ведеться в електронній формі українською мовою.

Щодо неподання декларації, то мається на увазі відсутність вчинення наступних дій. По-перше, декларація подається шляхом заповнення електронних форм відповідних документів на веб-сайті Реєстру відповідно до технічних вимог до форм. Електронну форму декларації осіб, уповноважених на виконання функцій держави або місцевого самоврядування затверджено рішенням Національного агентства з питань запобігання корупції від 10 червня 2016 р. № 3 [11].

По-друге, для того, щоб подати декларацію, суб’єкт на якого поширюється дія Закону України «Про запобігання корупції» повинен у власному персональному електронному кабінеті після реєстрації з використанням особистого ключа та посиленого сертифіката відкритого ключа електронного цифрового підпису в Єдиному державному реєстрі декларацій осіб, уповноважених на виконання функцій держави або місцевого самоврядування, подати декларацію через мережу Інтернет 3 використанням програмних засобів Реєстру. Після заповнення усіх необхідних полів форми документа суб'єкт декларування підписує документ накладанням на нього власного.

По-третє, кожному поданій декларації автоматично надано унікальний 


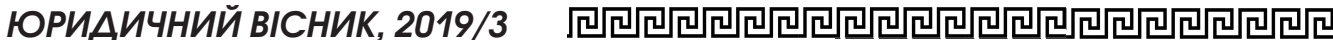

ідентифікатор документа та накладено на нього електронну печатку, що унеможливлює внесення несанкціонованих змін до поданого документа (забезпечує цілісність документа). Подання декларації підтверджується шляхом надсилання повідомлення суб'єкту декларування на адресу його електронної пошти, вказаної під час реєстрації в Реєстрі, та до персонального електронного кабінету суб'єкта декларування.

Щодо несвоєчасного подання, то ним вважається пропущення строків:

період з 00 годин 00 хвилин 01 січня до 00 годин 00 хвилин 01 квітня року, наступного за звітним роком - при поданні щорічної декларації, якою охоплено звітний рік (період з 01 січня до 31 грудня включно), що передує року, в якому подається декларація, та містить інформацію станом на 31 грудня звітного року;

не пізніше дня припинення діяльність, яку пов'язано 3 виконанням функцій держави або місцевого самоврядування - при поданні декларації суб’єктом декларування, який припиняє діяльність, пов'язану з виконанням функцій держави або місцевого самоврядування;

не пізніше двадцяти робочих днів з дня, коли суб'єкт декларування дізнався чи повинен був дізнатися про припинення діяльності, яку пов'язано 3 виконанням функцій держави або місцевого самоврядування;

до 00 годин 00 хвилин 01 квітня року, наступного за звітним роком, у якому було припинено таку діяльність - при поданні декларації суб'єкта декларування, який припинив діяльність, пов'язану з виконанням функцій держави або місцевого самоврядування, подається. Така декларація охоплює звітний рік (період з 01 січня до 31 грудня включно), що передує року, в якому подається декларація, та містить інформацію станом на 31 грудня звітного року;

до призначення або обрання особи на посаду при поданні декларації суб'єк- том декларування, який є особою, що претендує на зайняття передбачених законом посад. Така декларація охоплює звітний рік (період з 01 січня до 31 грудня включно), що передує року, в якому особа подала заяву на зайняття посади (участь у конкурсі), якщо інше не передбачено законодавством, та містить інформацію станом на 31 грудня звітного року [12].

Щодо суб’єкта проступку у вигляді порушення вимог фінансового контролю, то ним є фізична особа, яка здійснює особливий вид професійній діяльності. Відповідно до ст. 3 Закону України «Про запобігання корупції, до них віднесено:

1) осіб, уповноважених на виконання функцій держави або місцевого самоврядування (Президент України, Голова Верховної Ради України, його Перший заступник та заступник, Прем'єр-міністр України, Перший віце-прем'єр-міністр України, віце-прем'єр-міністри України, міністри, інші керівники центральних органів виконавчої влади, які не входять до складу Кабінету Міністрів України, та їх заступники, Голова Служби безпеки України, Генеральний прокурор, Голова Національного банку України, Голова та інші члени Рахункової палати, Уповноважений Верховної Ради України з прав людини, Голова Верховної Ради АРК, Голова Ради міністрів APK; народні депутати України, депутати Верховної Ради АРК, депутати місцевих рад, сільські, селищні, міські голови; державні службовці, посадові особи місцевого самоврядування тощо);

2) особи, які прирівняні до осіб, уповноважених на виконання функцій держави або місцевого самоврядування (посадові особи юридичних осіб публічного права; особи, які не є державними службовцями, посадовими особами місцевого самоврядування, але надають публічні послуги (аудитори, нотаріуси, приватні виконавці, оцінювачі, а також експерти, арбітражні керуючі, незалежні посередники, члени 
трудового арбітражу, третейські судді під час виконання ними цих функцій, інші особи, визначені законом); представники громадських об'єднань, наукових установ, навчальних закладів, експертів відповідної кваліфікації, які входять до складу конкурсних комісій, утворених відповідно до Закону Украіни «Про державну службу»);

3) особи, які постійно або тимчасово обіймають посади, пов'язані 3 виконанням організаційно-розпорядчих чи адміністративно-господарських обов'язків, або спеціально уповноважені на виконання таких обов'язків у юридичних особах приватного права незалежно від організаційно-правової форми, а також інші особи, які не $є$ службовими особами та які виконують роботу або надають послуги відповідно до договору з підприємством, установою, організацією, - у визначених законом випадках [1].

Висновки. Таким чином, підставою притягнення до адміністративної відповідальності за порушення вимог фінансового контролю $€$ вчинення особливого виду адміністративного правопорушення, якого спричинено корупцією. Визначено, що це правопорушення не містять ознак корупціï, але порушує встановлені законом вимоги, заборони та обмеження щодо здійснення публічної служби, вчиняється особами уповноваженими на виконання функцій держави або місцевого самоврядування, прирівняними до них, та особами, які постійно або тимчасово обіймають посади, пов'язані 3 виконанням організаційно-розпорядчих чи адміністративно-господарських обов'язків, або спеціально уповноваженими на виконання таких обов'язків у юридичних особах приватного права незалежно від організаційно-правової форми та посягає на права і свободи громадян, встановлений порядок управління. Вбачається доцільним подальше теоретичне дослідження практичного застосування норм антикорупційного законодавства за порушення вимог фінансового контролю.
Стаття присвячена висвітленню проблем, яких пов'язано із притягненням до адміністративної відповідальності за порушення фінансового контролю в Україні. Корупція - одна з найнебезпечніших для Украінн суспільство та державні події. Це підриває авторитет державного anapamy, дискредитує його робоmy, руйнуе основні принципи, на яких спирається будь-яка демократія, принципи рівності громадян перед законом. Закон про боротьбу з корупцією встановлюе кримінальну, адміністративну, циввільну ma дисииплінарну відповідальність за корупційні правопорушення та пов'язані з корупцією правопорушення відповідальних посадових осіб $\mathrm{ma}$ інших суб'єктів відповідальності. Крім того, доповнено декілька розділів Кодексу про адміністративні правопорушення, що призвело до посилення адміністративної відповідальності за корупизіині правопорушення. Це включає встановлення адміністративної відповідальності за порушення обмежень щодо порушення вимог фінансового контролю. Саме тому актуальність теми дослідження не викликає сумнівів. у статті проаналізовано склад адміністративного проступку у вигляді порушення фінансового контролю. Встановлено, що відповідальність за порушення вимог фінансового контролю може виникати за затримку подання особами, уповноважених на виконання функиій держави або місцевого самоврядування деклараиії, несвоєчасне повідомлення про відкриття рахунків в іноземній валюті в банківській установі, несвоєчасне повідомлення про значні зміни в майновому стані. У статmі визначено, що об'єктивна сторона правопорушення сформульована таким чином, що несвоєчасне (пізнє) подання декларації утворюе тривалу форму зловживань - порушення строку подання. Запропоновано шляхи вдосконалення процедури електронного 
декларування як запоруки належного здійснення публічної влади в Україні.

Ключові слова: фінансовий контроль, електронне декларування, правопорушення, яке пов'язано 3 корупцією, адміністративна відповідальність, об'єкт правопорушення.

$\begin{array}{lrr}\text { Reva } & \text { Yu. } & \text { FEATURES } \\ \text { OF } & \text { BRINGING } & \text { TO } \\ \text { ADMINISTRATIVE LIABILITY FOR } \\ \text { VIOLATION OF REQUIREMENTS } \\ \text { OF FINANCIAL CONTROL }\end{array}$

The article deals with the problems, wich related to administrative liability for financial control violations in Ukraine. Corruption - one of the most dangerous for society and state events. It undermines the authority of the state apparatus, discredit his work, destroys the basic principles on which rests any democracy, the principles of equality of citizens before the law. The Anti-Corruption Law sets criminal, administrative, civil and disciplinary liability for corruption offences and corruption-related offences for responsible Officials and other Subjects of Liability. The Anti-Corruption Law introduced a new wording to or supplemented several Sections of the Administrative Offences Code, resulting in increased administrative liability for corruption-related offences. This includes establishing administrative liability for violating the restrictions to violating the financial control requirements. That is why the relevance of the research topic is undeniable. In the article were analyzed administrative responsibility for corruption-related offenses, wich concerning violation financial control. Were determined that the offences provides for liability for violation of financial control, namely, delayed filing of the person authorized to perform state functions or local government, failure or late notification of opening foreign currency accounts in a banking institution or a non-resident of significant changes in economic status. That disposition is formulated so that the untimely (late) submission of the declaration forms a prolonged form of abuse - submission of infringement period (delay representation). Late filing - is its submission after the deadline. In the article were proposed ways to improved the electronic declaration procedure as a guarantee of proper exercise of public authority in Ukraine. So, based on the above, we can conclude that there is legislation in many conflicts which require urgent solution, and so further scientific research on this issue is necessary.

Key words: financial control, e-declarations, corruption-related offenses, administrative responsibility, the object of the offense

\section{Література}

1. Про запобігання корупиії: Закон України віә14.10.2014 № 1700-VII. Відомості Верховної Ради України. 2014. № 49. Cm. 3186 .

2. Кодекс України про адміністративні правопорушення: Закон України вї 07.12.1984 № 8073. URL: http:// zakon2.rada.gov.ua/laws/show /80731-10/ card6\#Public

3. Васьковиов А.О. Кваліфікація корупційних правопорушень, які пов'язані з порушенням встановлених законом обмежень. Часопис Академії адвокатури України. 2013. № 2. Cm. 1- 6 .

4. Мельник М. I. Корупція: сутність, поняття, заходи протидї : монографія. K.: Атіка, 2001. 304 c.

5. Кельман M.C. Загальна теорія держави і права: підручник. / М.С. Кельман, О.Г. Мурашин. К.: Кондор, 2006. 477 с.

6. Великий тлумачний словник сучасної української мови / уклад. і голов. ред. B.T. Бусел. К.; Ірпінь: Перун, 2003. 1440 с.

7. Великий енциклопедичний юридичний словник / за ред. акад. НАН України. Ю.С. Шемшученка. К.: Юридична думка, 2007. 992 c

8. Загальне адміністративне право: підручник / /Гриценко I. С., Мельник Р. С., Пухтецька А. А. та інші); за заг. ред. I. С. Гриценка. К. : Юрінком Iнтер, 2015. $568 \mathrm{c.}$.

9. Кодекс адміністративного судочинства України від 06.07.2005 р. (ред. від 
20.10 .2019 р.). № 2747-IV. URL: https:// zakon.rada.gov.ua/laws / show/2747-15

10. Біла-Тіунова Л.Р. Публічна служба як адміністративно-правова категорія. Наукові праці Одеської національної юридичної академії. Т. VIII / Редкол.: С.В. Ківалов (голов. ред.) та ін.; відп. за вип. Ю.М. Оборотов. Одеса : Юрид. л-ра, 2009. C. $142-154$.

11. Форма декларації осіб, уповноважених на виконання функиій держави або місиевого самоврядування запобі- гання корупції: Рішення Національного агентства з питань запобігання корупиіi віة 10.06.2016 № 3. Офіційний вісник України. 2016. № 55. Ст. 144.

12. Про функціонування Єәиного державного реєстру декларацій осіб, уповноважених на виконання функиій держави або місиевого самоврядування запобігання корупиї̈; Рішення Національного агентства з питань запобігання корупиіi від 10.06.2016 № 3. Офіційний вісник Украіни. 2016. № 55. Cm. 138. 